\title{
The Effect of Unemployment and Investment Levels on Economic Growth in the Province of Bangka Belitung Islands, 2015-2019
}

\author{
Reniati Reniati $^{1 *}$, Mohd Fauzi Kamarudin ${ }^{2}$, Rulyanti Susi Wardhani ${ }^{3}$, M.Faisal \\ Akbar $^{4}$ \\ ${ }^{1,3,4}$ Economics Faculty, Bangka Belitung University, Indonesia \\ ${ }^{2}$ Centre for Languages and Human Development, Universiti Teknikal Malaysia \\ Melaka, Malaysia. \\ *E-mail: reniati@ubb.ac.id
}

Received: January, 2020; Accepted: April, 2020; Published: May, 2020

Permalink/DOI: http://dx.doi.org/10.17977/um002v12i12020p068

\begin{abstract}
The purpose of this study was to analyze the effect of unemployment and investment on economic growth in The Province of Bangka Belitung Islands in 2015-2019. This study uses secondary data types with panel data structure at the Regency / City level in the Bangka Belitung Islands Province. In choosing the best method, this research also perform Hausman testing and Breuch Pagan LM testing to select the best alternative method in three models which have been proposed, namely fixed effect, random effect and Pooled OLS. The results showed that unemployment rate is not significantly influence economic growth in the Province of Bangka Belitung Islands in period 2015-2019, in contrast investing rate has a significantly positive effect on economic growth in the Province of Bangka Belitung Islands in period 2015-2019. So to increase economic growth, it is necessary to enhance investment in the Province of Bangka Belitung Islands.
\end{abstract}

Keywords: Unemployment, Investment, Economic Growth, Panel Data JEL Classification: E22, E24, O11

\section{INTRODUCTION}

The Province of Bangka Belitung Islands is an Archipelago Province which consists of two large islands namely Bangka Island and Belitung Island and 470 small islands in it and only 50 inhabited islands. As a relatively new province, the 31 st province in 2000 , continues to advance itself with all its own challenges, with Tin as the main driver of economic growth as well as the agriculture, plantation and fisheries sectors which remain the majority of the livelihoods of its population. The results of the evaluation of regional development achievements show that the economic growth performance of the Province of Bangka Belitung Islands has slowed in the last 5 years with an average growth of 4.4 percent (in 2014 to 2018). The Economic Growth of the Province of Bangka Belitung Islands even experienced a drastic decline in the $2^{\text {nd }}$ quarter of 2019 with a value of 3.49 percent, making it the province with the second lowest economic growth rate on the island of Sumatra. Although economic growth is low, unemployment and poverty rates are also low at the national level, this is certainly worth appreciating. The unemployment rate is 3.65 percent and the poverty rate is below 6 percent. 
The economy of the Province of Bangka Belitung Islands from 2014 to 2018 experienced an average growth of under 5 percent. This is not in accordance with the target of the local government of the Province of Bangka Belitung Islands in 2017 and 2018 which are 5.2 to 5.3 percent. This condition is caused by several economic problems. After conducting a deeper analysis based on the economic growth of the business sector, it is known that 2 leading business sectors experienced contractions in 2017, namely the agriculture, forestry and fisheries sectors which dropped drastically by -0.36 percent. While the mining sector also experienced a drastic slowdown from 2017 to 2018.

The process by which the government and all sections of society dominate the existing resources and subsequently build a partnership pattern between the local government and the private sector to form new jobs and stimulate the development of activities in the region called economic development (Nuraini, 2017; Pal et al., 2019). Economic development basically aims to improve the welfare of the community (Andhiani et al., 2018; Nafziger, 2012)

The increases of economic growth is one of important indicator to consider about the development of region or countries. According to Todaro (2014) specifically mentioned that there are three factors that influence economic growth, those are capital accumulation, population growth and matters related to the increase in the number of the workforce which are considered to positively stimulate economic growth. Economic growth is one of the pillars of the success of an area to move more advanced and productive. The government specifically provides stimulation for physical capital and the preparation of quality human resources to pursue a steady rate of growth. Unemployment, investment and economic growth are interrelated. (Baharin et al., 2012; Franita, 2016; Muhd Irpan et al, 2016)

The highest unemployment contributors in the Province of Bangka Belitung Islands came from SMK graduates and were followed by tertiary institutions. This shows that the availability of employment in the formal sector is still small for high school and above education circles and also the development of entrepreneurship must be further increased. This is an evident of the large number of commodity imports outside the Bangka Belitung region. However, elementary and junior high school graduates are actively getting jobs, especially in the mining sector and unconventional excavation or other informal sectors.

Bangka Island have a major problem to form a new investment. There are lack of incentive and facilities to investor build their company. Lack of forming the new investment make the unemployment going to rise. This problem need to be fixed by government with make some policies to stimulates the investors to do an investment.

Economic growth through the demand side is triggered by an increase in public consumption, while economic growth through the supply side is caused by an increase in the productivity of production factors such as labor, capital, technology transfer and the escalation of the quality of Human Resources (HR). Some literature and empirical models are the basis for analyzing the influence of economic and non-economic variables on economic growth. Growth models are expressed in terms of functional relationships between the dependent variable and a number of explanatory variables. The Neo-classical growth model 
as the basis for its analysis of the Cobb-Douglas production function in equation (1) (Barro, Robert J., 2006; Bowmaker, 2013)

$$
Y_{t}=A_{t} \cdot K_{t}^{\alpha} L_{t}^{\beta}
$$

Where:

Yt : growth rate in year $\mathrm{t}$.

At : level of technological progress in $\mathrm{t}$.

$\mathrm{Kt} \quad$ : total capital stock in year $\mathrm{t}$.

Lt : number of workers in year $\mathrm{t}$.

$\alpha, \beta \quad$ : production elasticity from capital and labor input.

Neo-Classical growth theory was developed Solow, 1956; Swan, (1956) using population growth variables, capital accumulation and technological advancement. In addition, the Solow-Swan model uses a production function that allows for a substitution between capital (K) and labor (L). The basic structural model of the Solow economic growth production function is as follows in equation (2):

$$
Y=F(K, L . .) \text {. }
$$

Conditions of constant returns to scale (constant scale returns) toward output can be formulated as follows in equation (3):

$Y=F(K, L)=L \cdot F(K / L, 1)=L \cdot f(k)$

Where:

$k=K / L$ is the ratio of working capital.

$y=Y / L$ is the number of output workers.

Furthermore it is stated that the capital stock is an output level determinant of an economy that can change over time and has implications for the rate of economic growth. Two forces that influence each other on the capital stock are investment ( ) and depreciation $(\delta)$. Investment refers to the addition of new equipment so that the capital stock increases, while depreciation $(\delta)$ refers to the use of capital which causes capital stock to decrease. Investment per worker as a function of the capital stock per worker is stated as follows in equation (4) and (5):

$i=s f(k)$

$\Delta k=i-\delta k$,

The higher the amount of capital stock, the greater the output (y) and investment (i), but conversely the amount of depreciation becomes greater. This process will continue until the level of depreciation $(\delta)$ equals investment (i). If the economy is at the level of a single capital stock $\mathrm{k} *$ (investment and balanced depreciation) where $\Delta \mathrm{k}=0$, then the economy is at a steady state level $\mathrm{k} *$ ( steady state level of capital). An economy that is not in equilibrium will tend toward a steady state ( steady state level) which shows a long-term economic balance.

A situation where someone is classified to the labor force wants to get a job but cannot get it (Bradley, 2016; Ibrahim et al., 2017; Susanto et al., 
2018). Individually unemployment raises economic and social problems for those who experience it (Hauwa, 2016). Theory developed by Ranis Fei, G, (1961) states that developing countries face the problem of overpopulation so that it will cause serious unemployment problems with the resources available and can be developed very limited (Suleiman et al., 2017)

Investment is one of the determinants that determines economic growth in developing countries. The decision to invest heavily depends on the opportunity to invest and the net number of positive values (Alvarado, Rafael, María Iñiguez, 2017) According to Arsyad (2015) investment is a sacrifice step towards current consumption to increase consumption in the future. In addition, investment encourages capital accumulation (Emeka et al., 2017). Adding stock of buildings and other important equipment will increase a nation's potential output and stimulate long-term economic growth. This investment has an active role in determining the level of output, and the rate of output growth depends on the rate of investment. (Onimisi, 2014). Furthermore, Jhingan, (2010) and Benjamin Badeji et al., (2011) mentions one of the effects of investment activities on the aggregate demand side that affects income when investment increases, aggregate expenditure will increase, which then increases regional income through a multiplier process.

\section{METHOD}

This study uses secondary data types with panel data structure at the Regency / City level in the Bangka Belitung Islands Province. In analying the factors affecting economic growth from the supply side, there are 3 variables that will be included in the regression model, including GRDP variable expenditure on constant 2010 prices in each regency / city, open unemployment rate for each regency city as well as gross fixed capital formation in every regency in the city. Bangka Belitung Islands Province.

The use of panel data regression has several advantages including: Panel data is capable of calculating individual heterogeneity explicitly by allowing individual specific variables. This ability to control heterogeneity further makes panel data usable to test and construct more complex behavioral models, panel data is based on cross-observation time series, so that the panel data method is suitable for use as a study of dynamic adjustment. the high number of observations has implications for data that are more informative, more varied, and collinearity between data decreases, and degrees of freedom (df) are higher so that more efficient estimation results can be obtained. (Gujarati, 2004; Verbeek, 2000)

In choosing the best method, the study also tested Hausman and Breuch Pagan LM testing to select alternative best method in three models which have been proposed, they are fixed effect, random effect and Pooled OLS. (Widarjono, 2007)

The technique used in the Random Effect Method is to add error terms (error terms) that might appear in the relationship between time and between districts / cities. OLS method techniques cannot be used to obtain efficient estimators, so it is more appropriate to use the Generalized Least Square (GLS) Method (Gujarati, 2004).

The following is the formulation of the Random Effect regression model used in testing hypotheses: 


$$
\log (P D R B)_{i t}=\beta_{0}+\beta_{1} \log (I)_{i t}+\beta_{2} U n_{i t}+\varepsilon_{i}
$$

Whereby:

\begin{tabular}{|c|c|}
\hline$i$ & $=$ district $/$ city \\
\hline 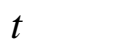 & $=$ period \\
\hline$P D R B$ & $=\log$ GDP GDP at constant prices \\
\hline Un & $=$ unemployment rate \\
\hline$I$ & $=\log$ gross capital formation \\
\hline$\varepsilon_{i t}$ & $=$ error term \\
\hline
\end{tabular}

This research conducted directed examination with of one-tailed to each variable. It is known that Cobb Douglas explained that the component of capital will provide stimulation to the increase in economic capacity so it can be assumed that the formation of gross capital has a significant and positive impact on the level of GRDP.

$\frac{\partial P D R B_{i t}}{\partial I_{i t}}=\beta_{1}$

And

$$
\beta_{1}>0
$$

Value $\beta_{1}>0$ indicates that the rate of change in gross capital formation in a regency / city in the Province of Bangka Belitung Islands will have a positive influence on the rate of change in GDP (economic growth). So the hypothesis is that unemployment has a significant effect on economic growth. And investment has a significant effect on economic growth.

\section{RESULTS AND DISCUSSION}

The data used in this study is secondary data released by the Central Statistics Agency for regencies and cities in the Bangka Belitung Islands Province. Consider the following table:

Table 1. Description of data

\begin{tabular}{llllll}
\hline Variable & Obs & $\begin{array}{l}\text { The } \\
\text { mean }\end{array}$ & Std. Dev & Min & Max \\
\hline Economic growth & 56 & 4.827143 & 1.163125 & 0.31 & 6.91 \\
Unemployment Rate & 49 & 4,050612 & 2.017952 & 1.21 & 10.64 \\
Gross Capital Formation & 56 & 1498361 & 416307.8 & 954702 & 2671775 \\
GRDP & 56 & 6760935 & 1996281 & 3798788 & $1.18 \mathrm{E}+07$ \\
\hline
\end{tabular}

Source: (Central Statistics Agency, 2019)

The data shows that the average open unemployment rate in the Province of Bangka Belitung Islands is at the level of 4.05 percent. While the rate of economic growth from 2011 to 2018 was at the level of 4.8 percent. The Province of Bangka Belitung Islands has experienced economic downturn in the last 5 years.

Furthermore, there is an information vacancy on the opened unemployment rate in 7 districts of the Bangka Island Province City. It was 
explained that the Central Statistics Agency did not release data on open unemployment rates in 2016.

\section{Economic Growth Data}

The data shows that economic growth in Bangka Belitung has slowed down due to the factor of tin business which is getting smaller and the price of agricultural products getting cheaper. Consider the following picture:

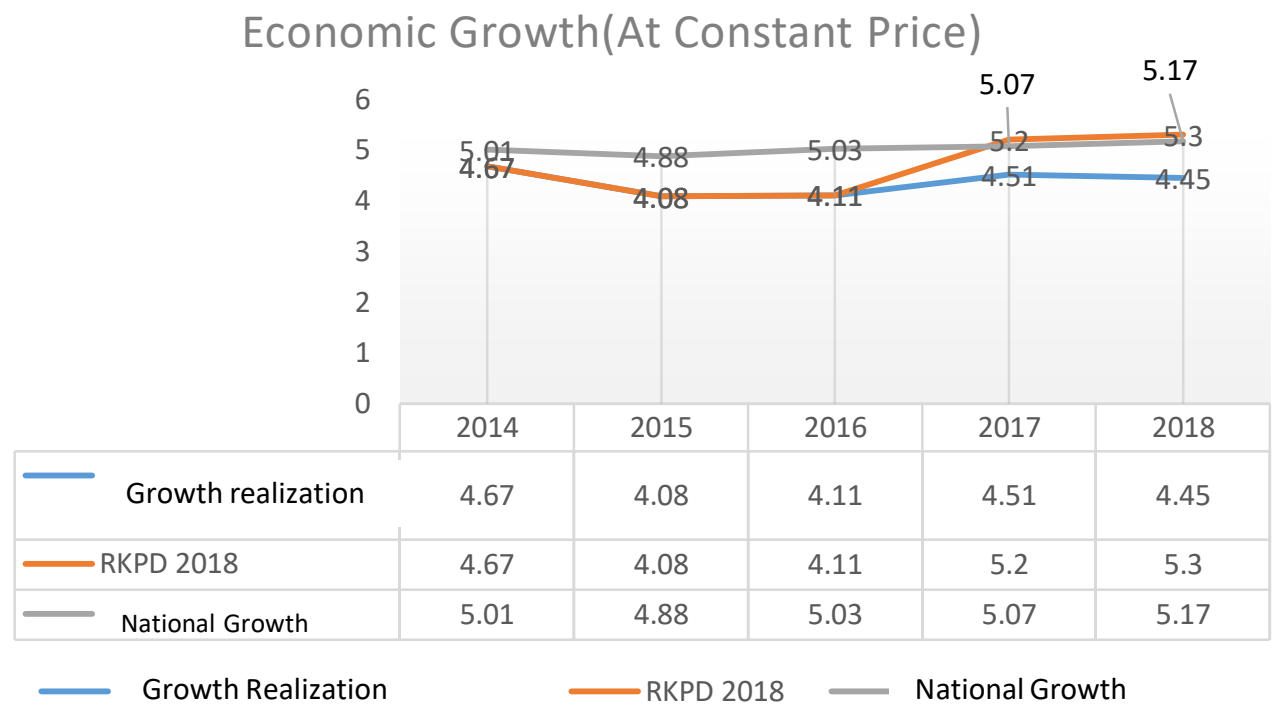

Figure 1. Economic Growth Rate (ADHK)

Source: (Badan Pusat Statistik, 2019) Processed

The economy of the Province of Bangka Belitung Islands from 2014 to 2018 experienced an average growth number under 5 percent. Economic growth in the Pacific Islands has not been able to pass the achievement of national economic growth.

\section{Data of Gross Domestic Capital Formation}

Data shows that the formation of gross domestic fixed capital in all regencies/cities in the province of Bangka Belitung Islands has increased. Central Bangka Regency experienced a significant growth starting in 2013 until 2018 so as it is an area with the highest level of gross capital formation. Significant gross capital growth was also experienced by Bangka Regency in 2010 to 2016. However, the formation of gross capital in Bangka Regency slowed in 2017 and 2018 . 


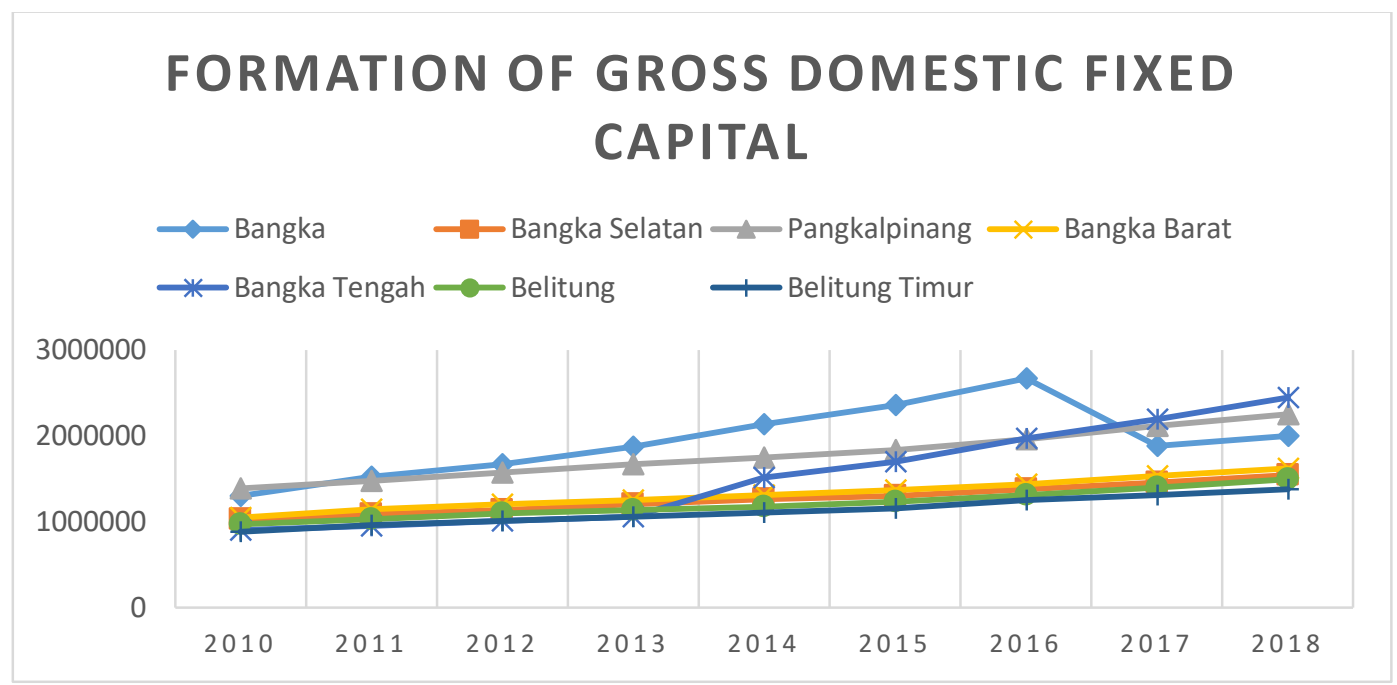

Figure 2. Formation of Gross Domestic Fixed Capital per Regency / City Source: Badan Pusat Statistik, 2019 (processed)

The formation of gross domestic fixed capital of following districts such as South Bangka, West Bangka, Belitung, East Belitung and Pangkalpinang have increased every year and the increase tends to be stable and gradual.

\section{Data of Unemployment Rate}

Data released from BPS in the Province of Bangka Belitung Islands experienced problems in 2016 so unemployment data was only available on a Provincial scale only. Consider the following data:

Table 2. Distribution of Unemployment (August) District / City

\begin{tabular}{llllllllll}
\hline \multirow{2}{*}{ Territory } & \multicolumn{1}{c}{ Open Unemployment Rate } \\
\cline { 2 - 11 } & $\mathbf{2 0 1 0}$ & $\mathbf{2 0 1 1}$ & $\mathbf{2 0 1 2}$ & $\mathbf{2 0 1 3}$ & $\mathbf{2 0 1 4}$ & $\mathbf{2 0 1 5}$ & $\mathbf{2 0 1 6}$ & $\mathbf{2 0 1 7}$ & $\mathbf{2 0 1 8}$ \\
\hline Bangka & 6.47 & 3.15 & 2.77 & 4.26 & 8.36 & 8.87 & - & 4.29 & 4.12 \\
Belitung & 3.77 & 2.97 & 1.76 & 2.59 & 3.03 & 4.57 & - & 2.57 & 2.93 \\
West Bangka & 4.19 & 3.64 & 3.79 & 3.91 & 1.21 & 5.92 & - & 4.23 & 3.11 \\
Central Bangka & 6.65 & 3.21 & 4.54 & 3.47 & 5.64 & 6.58 & - & 3.38 & 3.93 \\
South Bangka & 4.07 & 3.92 & 3.83 & 1.64 & 3.26 & 2.01 & - & 2.74 & 4.35 \\
East Belitung & 3.98 & 2.51 & 2.42 & 2.2 & 2.61 & 2.55 & - & 2.62 & 1.5 \\
Pangkalpinang City & 9.37 & 5.63 & 5.25 & 6.66 & 8.84 & 10.64 & - & 5.8 & 4.7 \\
\hline
\end{tabular}

Source: Badan Pusat Statistik, 2019 (processed)

Data shows that in 2017 the district of east Belitung had the lowest Unemployment Rate with a value of 2.62 percent. While the highest unemployment rate in 2017 was in Bangka Regency with an unemployment rate of 4.29 percent. East Belitung Regency even experienced a significant decrease of the unemployment rate where in 2018 it was only 1.5 percent, the highest unemployment rate in 2018 was South Bangka Regency. 


\section{Regression Result}

This study calculates using 3 alternative approaches, namely Fixed Effect, Random Effect and Pooled OLS . Consider the following results:

Table 3. The Results of Calculations Using 3 Alternatives

\begin{tabular}{llll}
\hline Variable & Fe.P & Re.P & Ols.P \\
\hline Unemp. & 0.004954 & 0.00460051 & 0.00884968 \\
logcapital & $0.007174117 * * *$ & $0.7189162^{* * *}$ & $0.88678616^{* * *}$ \\
_cons & $5.4891077 * * *$ & $5.4673691 * * *$ & 3.072107 \\
\cline { 2 - 4 } & Legend: ${ }^{\mathrm{p}}<0.05$ & $* * \mathrm{p}<0.01$ & $* * * \mathrm{p}<0.001$ \\
\hline
\end{tabular}

In deciding the best alternative method, a Hausman test is used to determine the best model between fixed effects and random effects. The results are as follows:

Table 4. Hausmann Test

\begin{tabular}{lcccc}
\hline & (b) & (B) & $($ b-B) & Sqrt(diag(V_b-V_B $))$ \\
& Fe.P & Re.P & Difference & S.E. \\
\hline Unemp. & 0.0044954 & 0.0046005 & -0.0001051 & 0.0005254 \\
Logcapital & 0.7174117 & 0.7189162 & -0.0015045 & 0.0041899 \\
\hline
\end{tabular}

Prob $>$ chi $2=0.961$

The results show that 'Prob $>$ chi2' $>0.05$, which shows that the random effect is a method that is more appropriate. Next we will test the alternatives between random effects and pooled least square. To test the best estimation between random effects and pooled least square we use the LM test. From the LM test we find that prob $>$ chibar 2 has a value of $<0.05$ which means that the best alternative in choosing a calculation method is to use a random effect model.

After conducting calculation using the random effect model, it is known that the independent variable as a whole is able to explain the movement of the GRDP level in the Province of Bangka Belitung Islands and its City. The results show that the unemployment rate variable, and gross domestic capital formation are able to explain the GRDP level variable of 68.05 percent. While the rest is influenced by other variables outside this model (error). The following is empirical model:

$P D R B_{i t}=5,46+0,718 I_{i t}+0,004 U n_{i t}+\varepsilon_{i}$

The results show that if there is no change in the level of domestic fixed capital formation and the unemployment rate, the GRDP value individually will continue to increase by 4.56 percent annually. Furthermore the results show that the level of domestic fixed capital formation has a positive and significant impact on the level of GRDP. An increase in the rate of formation of domestic fixed capital by 1 percent will increase the value of GRDP by 0.718 percent. These results indicate that the findings are in accordance with the hypothesis that was described at the beginning of the study.

An interesting thing that was found in this study was there is no significance of the effect between the unemployment variable and the GRDP score. This indicates that changing the non-work status to work status from 
community does not necessarily contribute to an increase in GRDP of the Bangka Belitung Islands Province. For this reason, the issue that was found in this result is that the productivity of the people in The Province of Bangka Belitung Islands are still low.

\section{CONCLUSION}

Based on the results of research and discussion, thus can be concluded that the unemployment rate does not significantly influence economic growth in the Province of Bangka Belitung Islands in the 2015-2019 period. Furthermore, the level of investment has a significantly positive effect on economic growth in the Province of Bangka Belitung Islands in the Period of 2015-2019.

\section{ACKNOWLEDGEMENT}

We would like to express our highest gratitude and appreciation to some our parties, firstly to Bappenas who have provided funding to conduct a Regional Development Evaluation study, secondly to Bappeda of Bangka Belitung Islands Province, which has facilitated several FGD activities related to this research . The three Chancellors and LPPM Bangka Belitung University who have given us the trust to become a Research Team.

\section{REFERENCES}

Onimisi, A. T. (2014). Foreign direct investments and employment generation nexus in Nigeria. Journal of Educational and Social Research, 4(5), 119119.

Alvarado, R., Iniguez, M., \& Ponce, P. (2017). Foreign direct investment and economic growth in Latin America. Economic Analysis and Policy, 56, 176-187. https://doi.org/https://doi.org/10.1016/j.eap.2017.09.006.

Andhiani, K. D., Erfit, E., \& Bhakti, A. (2018). Analisis pertumbuhan ekonomi dan ketimpangan pembangunan di Wilayah Sumatera. e-Jurnal Perspektif Ekonomi dan Pembangunan Daerah, 7(1), 26-34.

Arsyad, L. (2015). Economic Development 5th ed. Yogyakarta: UPP STIM YKPN.

Baharin, N., Yussof, I., Ismail, R., \& dan Pengurusan, F. E. (2012). Faktor-faktor yang Mempengaruhi Pengangguran di Malaysia. Prosiding Persidangan Kebangsaan Ekonomi Malaysia (PERKEM), 1, 209-227.

Barro, R. J., \& Sala-i-Martin, X. (1992). Public finance in models of economic growth. The Review of Economic Studies, 59(4), 645-661.

Omoniyi, B. B., \& Omobitan, O. A. (2011). The impact of foreign direct investment on economic growth in Nigeria. International Research Journal of finance and economics, 73, 122-132.

Bowmaker, S. W. (2010). The Heart of Teaching Economics. Books.

Bailly, J. L., Cencini, A., \& Rossi, S. (Eds.). (2016). Quantum Macroeconomics: The Legacy of Bernard Schmitt. Taylor \& Francis.

Ibrahim, D. H. M., \& Mahyuddin, M. Z. (2017). Youth Unemployment in Malaysia: Developments and Policy Considerations. Outlook and Policy, Annual Report. 
Emeka, A., Idenyi, O. S., \& Nweze, N. P. (2017). Domestic investment, capital formation and economic growth in NIGERIA. International Journal of Research in Social Sciences, 7(2), 41-65.

Jajere, H. B. (2016). Impact of Unemployment on Economic Growth in Nigeria 1980-2010. Journal of Business and Finance Management Research, 2(10).

Jhingan, M. L. (2016). The Economics of Development and Planning, terj. $D$. Guritno, Ekonomi Pembangunan dan Perencanaan. Jakarta: Rajawali Pers.

Irpan, H. M., Saad, R. M., Nor, A. H. S. M., Noor, A. H. M., \& Ibrahim, N. (2016, April). Impact of foreign direct investment on the unemployment rate in Malaysia. In Journal of Physics: Conference Series (Vol. 710, No. 1, p. 012028). IOP Publishing.

Pal, D., Chakraborty, C. and Ghose, A. (2019), "Joint Estimation of Fiscal Policy, Income Inequality, Trade and Economic Growth: Evidence from Emerging Market Economy", Bhattacharyya, R. (Ed.) The Gains and Pains of Financial Integration and Trade Liberalization, Emerald Publishing Limited, pp. 89-100. https://doi.org/10.1108/978-1-78973-999-220191014

Ranis, G., \& Fei, J. C. (1961). A theory of economic development. The american economic review, 533-565.

Solow, R. M. (1956). A contribution to the theory of economic growth. The quarterly journal of economics, 70(1), 65-94.

Statistik, B. P. (2019). Statistik daerah provinsi kepulauan bangka belitung.

Suleiman, S. H., Kassim, S. T., \& Moh'd Hemed, I. (2017). Unemployment and Economic Growth in Tanzania. Journal of Economics, Management and Trade, 1-8. https://doi.org/https://doi.org/10.9734/jemt/2017/38500.

Susanto, E., Rochaida, E., \& Ulfah, Y. (2018). Pengaruh inflasi dan pendidikan terhadap pengangguran dan kemiskinan. Inovasi, 13(1), 19-27. https://doi.org/https://doi.org/10.29264/jinv.v13i1.2435

Swan, T. W. (1956). Economic growth and capital accumulation. Economic record, 32(2), 334-361. https://doi.org/https://doi.org/10.1111/j.14754932.1956.tb00434.x

Verbeek, M. (2008). A guide to modern econometrics. John Wiley \& Sons.

Widarjono, A. (2007). Ekonometrika: teori dan aplikasi untuk ekonomi dan bisnis. Yogyakarta: Ekonisia. 